\title{
MAKERERE COLLEGE
}

$\mathrm{T}$

HE School of Agriculture at Makerere College, the University College of East Africa, was opened by the Visitor, H.E. Sir Frederick Crawford, on March 13 in the presence of the Council of the College, its Principal, academic staff, past and present students and many visitors representative of diverse fields of work in East Africa. Prior to the opening, the main entrance of the building was hidden behind a screen of papyrus and local grasses. Sir Frederick, wielding an omuhoro, an agricultural implement from south west Uganda, made for himself a path to gain entry to the School.

The School is placed on a commanding site on the ridge of Makerere Hill and from nearly every room there is an extensive view. The architects were the Kampala firm of Cobb, Powell and Freeman; Mr. Roger Freeman and Mr. R. E. Manwaring having been particularly responsible. They have produced a light, spacious and airy building of graceful proportions and dignified appearance. They have indeed served the College well in making the best use of the $£ 83,000$ which was allocated for the building out of a grant of $£ 250,000$ given by the East African Governments for the development of the Faculty of Agriculture at Makerere and $£ 30,000$ from Colonial Development and Welfare funds.

The building is a two-story one, the general shape of which may be seen from Fig. 1. A central projection to the west housés two lecture theatres, each seating 125. Much thought went into the designing of special seats so that a through-current of air would not be impeded by massive woodwork, an important matter for lectures given at latitude $0^{\circ} 20^{\prime} \mathrm{N}$. It is hoped that the slatted black-out blinds and doors will make it possible to project films and slides without the audience suffering discomfort.

In the central area there are also a large room for seminars and conferences, a reading room, museum, small service room and cloakrooms. This area can be completely shut off by doors from the other parts of the building so that it is possible to use it for conferences without disturbing the general life of the School. Beyond these doors, on both floors and facing north-east, are private workrooms for the senior members of the Faculty. At present not all these rooms have occupants, but the School has been built to allow for the expansion which should undoubtedly take place over the next ten years.

The north wing houses the Division of Agricultural Chemistry, with a small lecture room which may also be used for examinations and two large teaching laboratories for soil science and pedology and for organic chemistry. Each will hold thirty-two students and each has its own balance room. There are also a number of smaller laboratories for members of staff and research students. This wing has an extensive stores area, which is essential where most



Fig. 1. The School of Agriculture, Makerere College 
equipment and supplies have to be imported and large stocks must therefore be carried. A rear access road leads up to the door of this area, and there is an unloading ramp leading into a wide passage-way where goods may be unpacked protected from the weather and predators.

The south wing contains the agricultural botany and agricultural zoology teaching laboratories, and there is a smaller laboratory for teaching animal physiology, one for advanced students and a number of small laboratories for research.

An important adjunct to the central and research building is the University farm, Kabanyolo, 11 miles from Makerere College and close to the Empire Cotton Growing Corporation's main research centre at Namulonge.

We have been fortunate in that we have been able to settle in the new School of Agriculture a few months before the opening of the course for the B.Sc. (Agriculture) degree in special relation with the University of London. As the Faculty develops, we hope that we shall be a centre not only for teaching but also for research, attracting workers from East Africa and beyond. We have undoubtedly been given the physical conditions in which these may proceed.
Margaret A. Keay

\section{CONSERVATION OF NATURE IN SOUTH-EAST ENGLAND}

\begin{abstract}
CONFERENCE on "Conservation of Nature in South-east England", convened by the Southeastern Union of Scientific Societies, was held in the rooms of the Zoological Society of London on April 12, under the chairmanship of the Earl of Cranbrook.

The first paper was on "The Invertebrate Fauna of the Chalk Country and its Conservation". Mr. John Sankey commenced by commenting on the general lack of knowledge of invertebrate ecology, which was surprising when one considers the tremendous amount of collecting which must have been done in the chalk country of south-east England. It is a great pity that collectors have not published more records. He said that before one can speak of the conservation of animals it is necessary to know which animals we want to conserve and this needs a detailed survey of the invertebrate life of chalk country. Like a great deal of present-day synecological work a team of specialists is required for such an undertaking. Even when comprehensive lists are available there still remains the task of sorting, collating and
\end{abstract} interpreting the information.

Since all animals are dependent on the vegetation and the plants are dependent upon the soil, rock, climate and other physical factors, it follows that the zoological ecologist should also have at least a working knowledge of these subjects. Finally, he must be able to assess the effects of biotic factors in the environment. To anyone who has collected invertebrate animals in our chalklands the rich variety and frequent abundance of many species must be apparent. Such a type of fauna lends itself to fairly effective sampling methods. The proper approach would seem to be in the choice of a number of typical sample areas on the chalk. It will be necessary to consult the botanists when choosing places for intensive study, though one can be entirely dependent on what they may describe as areas of typical chalk country because animals, unlike plants, move about and they often occur quite commonly in places which have been disturbed and which botanically are not typical of the chalk. If, by sampling and listing, we can determine which are the richest and most typical areas of the chalk invertebrate fauna, then we have a basis for conservation of this fauna. Mr. Sankey concluded by saying that it is only through a sound knowledge of the ecology of animals that their conservation can be successfully effected.

Mr. Maxwell Knight spoke upon "The Vertebrates of Frensham Ponds and Romney Marsh". He said he would like to approach the question as if it were the point of view of the animals themselves. If the animals were to be protected, the protection of the environment was necessary. Using the natterjack toad as an example, he said that whereas a few years ago hundreds were present at the large pond at Frensham, to-day, owing to human interference, none existed. Some had become established at the small pond but commercial interference, including boating and fishing, threatened their extinction. The haunt of the natterjack, the reed marshes, had been cleared. The removal of the reeds changed an environment essential for their existence, for the breeding period was a long one, spreading from April to June, so adults, young and tadpoles were together at the same time; at others tadpoles and spawn were together. $\mathrm{He}$ next spoke of the sand lizard and its curious distribution. One type, with subdued small markings, occurs in the south as far as Dorset; then there was a belt across the country from which they are absent until Lancashire is reached, when a type with pronounced blotches occurs. At Frensham within a few miles of each other both types exist. The colonies move from year to year, in hot years tending to approach the ponds where the dew helps to increase the number of spiders upon which they feed.

The smooth snake is becoming increasingly rare in the area, but it may be more widely distributed than is supposed for it does not bask in the sun but either goes to earth or seeks cover under large stones. The conservation of an area which would permit the breeding of small rodents upon which it feeds is desirable.

Mr. Maxwell Knight concluded by speaking of the introduction of a few pairs of marsh frog during 1935 into Romney Marsh. It became sufficiently numerous within a few years to have a question asked in the House of Commons regarding its nuisance. Recently there has been a considerable reduction in numbers, possibly due to the fall in the freshwater shrimp population. The question of the desirability of protecting an introduced animal was discussed. The effect of its introduction upon the water population was the disappearance of the common frog and toad, the newt and some of the dragonflies. On the beneficial side it was said that there was an absence of mosquitoes since the introduction of the marsh frog.

Dr. Francis Rose chose as his subject "Possible Nature Reserves in Kent, Sussex and Surrey: a Botanical Ecologist's Viewpoint". He said he wished to deal with his subject under two headings, the plant communities and flora of the Wealden counties; and nature conservation in this region. 